\title{
PENGHAYATAN ISLAM DAN HUBUNGANNYA DENGAN KONFLIK RUMAHTANGGA: KAJIAN DI UNIT RUNDING CARA, BAHAGIAN UNDANG- UNDANG KELUARGA, JABATAN AGAMA ISLAM SELANGOR
}

\section{The Relationship between the Implementation of Islamic Values with Domestic Conflict: A Study at the Consultation Unit, Islamic Family Law Division of Selangor Department of Islamic Affairs}

\author{
Nurhanisah Hadigunawan ${ }^{1}$ \\ Raihanah Azahari²
}

\begin{abstract}
Islamic values are the performance and implemention of every command of Allah SWT, which covers all aspects of living and should be based on knowledge, comprehension, and practice. Islamic values are also an effort to improve the relationship between human beings and Allah SWT to gain happiness in here and hereafter. This study analyses and discusses the level
\end{abstract}

\footnotetext{
Master Candidate, Department of Fiqh and Usul, Academy of Islamic Studies, University of Malaya, 50603 Kuala Lumpur,

2 Associate Professor, Department of Fiqh and Usul, Academy of Islamic Studies, University of Malaya, 50603 Kuala Lumpur, raihan@um.edu.my
} 
of implementation of Islamic values among conflicting spouses together with the cause of its neglect and also looks at the relationship between the implementation of Islamic values and domestic conflicts. This study was performed through conducting structured and unstructured interviews on 10 conflicting spouses who are undergoing counselling at the Consultancy Unit, in the Family Law Division of Selangor Islamic Religious Department (JAIS). The findings show that belief and worship is not related directly to family conflicts. However, Islamic values are closely related to attitude because there are other factors that must be emphasised by spouses in preventing serious family conflict, which are forming positive attitudes on oneself and having knowledge in family affairs and practicing said knowledge so that family abuse and cruelty do not occur. Thus, Islamic values play an important role as an instrument that connects human beings with their Creator in asking for solutions to problems they are facing and presenting tranquillity in tense situations.

Keyword: implementation of Islamic values, family, marriage, conflict, consultation

\section{PENGENALAN}

Islam adalah agama yang syumul dan setiap perkara yang terkandung di dalamnya tidak memberi makna sekiranya tidak dihidupkan dengan penghayatan oleh penganutnya. Penghayatan Islam membawa maksud melaksanakan dalam bentuk amali ajaran Islam dengan segala cakupan yang ada padanya secara komprehensif dan ianya haruslah berakar umbi kepada pengetahuan, kefahaman dan pengamalan. ${ }^{3}$ Asas dalam penghayatan Islam merangkumi tiga prinsip iaitu akidah ${ }^{4}$ sebagai teras dalam agama Islam dan

3 Nor Salimah Abu Mansor, 'Penghayatan Agama Sebagai Wahana Memperkasa Nilai Insan: Kajian Konsep Berdasarkan Pandangan Sarjana Islam,' (Makalah, Seminar Kebangsaan Pengajian Umum, Jabatan Pembangunan Sumber Manusia, Fakulti Pengurusan dan Pembangunan Sumber Manusia, Universiti Teknologi Malaysia, 13-14 Jun 2006).

4 Perkataan akidah diambil dari kata dasar al- 'aqdu. Akidah dari segi bahasa ialah janji atau satu keyakinan yang menjadi pegangan yang kuat. Lihat Ibn Manzūur, Muhammad Ibn Mukarram, Lisān al- 'Arab, vol. 3 (Beirūt: Dār al-Ṣādir, 1994), 297. Dari segi istilah pula akidah ialah kepercayaan dan keyakinan yang cukup pasti dan muktamad terhadap sesuatu tanpa sebarang syak dan keraguan. Lihat Mușțafā, Ibrāhīm et al., al-Mu jam al-Wasìt, vol. 1 (Istanbul: Maktabah alIslāmiyyah, 1972), 613-614. 
Penghayatan Islam dan Hubungannya dengan Konflik Rumahtangga: Kajian di Unit Rundingcara, Bahagian Undang-Undang Keluarga, Jabatan Agama Islam Selangor

pegangan hidup orang mukmin, Syariah ${ }^{5}$ berkaitan dengan amalan dan tingkah laku orang Islam dan akhlak ${ }^{6}$ sebagai etika hidup yang merupakan manifestasi daripada akidah yang jelas dan Syariah yang mantap.?

Konflik rumah tangga pula bermaksud sebarang bentuk perselisihan atau pertentangan pendapat, kehendak serta perancangan ${ }^{8}$ di antara suami isteri dan berkemungkinan besar boleh mengganggu sistem keharmonian sesebuah rumah tangga. ${ }^{9}$ Konflik melibatkan gangguan kepada beberapa elemen penting sesebuah institusi keluarga iaitu perasaan, pemikiran, tingkah laku dan sistem kepercayaan serta konsep nilai. ${ }^{10}$ Dalam Islam, terdapat tiga bentuk konflik rumah tangga iaitu nusyuz; ${ }^{11}$ melibatkan salah satu pihak sahaja dan konflik yang melanda dapat diselesaikan di antara suami isteri itu sendiri tanpa

5 Syariah menurut bahasa ialah jalan yang lurus. Dari segi istilah pula ialah hukumhakam yang telah ditetapkan oleh Allah SWT kepada hamba-Nya berkaitan dengan akidah, ibadat, akhlak, muamalat, dan sistem hidup dalam pelbagai aspek demi untuk kebahagiaan mereka di dunia dan akhirat. Lihat Madkūr, Muhammad Sallām, al-Madkhal ila al-Figh al-Islāmī, vol. 1 (al-Qāhirah: al-Dār al-Qawmiyyah, 1955), 11.

$6 \quad$ Akhlak didefinisikan sebagai keadaan jiwa yang menggerakkan seseorang untuk melakukan sesuatu perbuatan tanpa pertimbangan fikiran terlebih dahulu. Lihat Ibn Miskawayh, Aḥmad Ibn Muḥammad, Tahdhīb al-Akhlāq (Beirūt: Manshūrāt Dār Maktabat al-Ḥayāt, 1961), 36. Lihat juga Mubārak, Zākī, Akhlāq 'inda alGhazālī (al-Qāhirah: al-Sha'ab, 1971), 161.

7 Solahuddin Abdul Hamid, 'Penghayatan Agama sebagai Motivasi Keinginan Pencapaian: Kajian Usahawan Melayu Mara Kedah,' (Tesis Kedoktoran, Akademi Pengajian Islam, Universiti Malaya, 2012), 15.

8 Mahoney, Annette, 'Religion and Conflict in Marital and Parent-Child Relationships,' Journal of Social Issues, 61/4 (2005): 689-706.

9 Norhayati Hamzah, 'Menangani Konflik Institusi Perkahwinan: Analisisi dan Pandangan Al-Qur'an,' (Makalah, Seminar Falsafah Perkahwinan, Pusat Pembangunan Keluarga, Universiti Malaya, 29-30 Mac 2006), 1-19.

10 Siti Fatimah Abdul Ghani \& Haslee Sharil Lim Abdullah, 'Perkhidmatan Kaunseling Keluarga: Satu Alternatif dalam Pengurusan Konflik Rumahtangga,' Masalah Pendidikan (2006): 67-79.

11 Nusyuz adalah pelanggaran komitmen bersama antara suami isteri terhadap apa yang menjadi kewajipan dalam rumah tangga. Lihat Abu Hassan Din, Krisis Rumahtangga \& Cara Mengatasinya (Kuala Lumpur: Darul Nu'man, 1996), 91. Lihat juga al-Fayrūzābādī, Muḥammad Ibn Ya'qūb, al-Qāmūs al-Muhīṭ, vol. 2 (alQāhirah: Maktabah Dār al-Ma’mūn, 1938), 194. 
perlu kepada pertolongan pihak ketiga, syiqaq; ${ }^{12}$ melibatkan perbalahan atau perselisihan yang berterusan antara kedua-dua belah pihak dan melibatkan pihak ketiga untuk menyelesaikannya dan darā $r{ }^{13}$ situasi di mana isteri mengalami penderaan atau penganiyaan daripada suami yang menyebabkan bahaya atau kemudaratan terhadap nyawa, akal, keturunan, harta dan agama isteri.

Ajaran Islam perlu diamalkan dalam seluruh aspek kehidupan manusia terutamanya dalam institusi kekeluargaan. Ini kerana, untuk mencapai kebahagiaan rumah tangga memerlukan tiga unsur penting iaitu ketenangan jiwa (sakinah), cinta mencintai (mawaddah) dan kasih sayang (rahmah). ${ }^{14}$ Ketiga-tiga unsur ini hanya dapat dirasai melalui iman yang jitu dan amalan yang soleh. ${ }^{15}$

Banyak kajian membuktikan agama mempunyai perkaitan yang kuat dengan kekukuhan sistem kekeluargaan. Dollahite ${ }^{16}$ menyatakan bahawa agama memberi pengaruh pada perkahwinan melalui peningkatan nilai-nilai moral dan kualiti hubungan yang mampu menjamin kebahagiaan keluarga dan menghindarkan pasangan daripada melakukan perkara-perkara yang dilarang oleh tuhan. Ini selari dengan kajian Robinson ${ }^{17}$ yang menyatakan agama boleh memberi kesan kepada kestabilan rumah tangga melalui bimbingan moral dan juga pertumbuhan sosial, emosi dan rohani yang baik dalam kalangan suami isteri.

12 Syiqaq berpunca daripada kederhakaan isteri terhadap suami atau kazaliman suami terhadap isteri yang lebih dikenali sebagai nusyuz isteri atau suami. Lihat al-Rāzī, Fakhr al-Dīn Muhammad Ibn 'Umar, al-Tafsīr al-Kabìr, vol. 10 (al-Qāhirah: Mu'assasat al-Mațba'ah al-Islāmiyyah, 1938), 87-88.

13 Darar ialah hak-hak isteri telah dicabuli, diderai dan disakiti oleh suami sama ada fizikal, mental dan seksual. Lihat Raihanah Abdullah, 'Alasan Membubarkan Perkahwinan Melalui Fasakh,' Jurnal Syariah, 5/1 (1997): 51-62.

14 Nur Zahidah Jaapar \& Raihanah Azahari, 'Model Keluarga Bahagia Menurut Islam,' Jurnal Fiqh, 8 (2011): 25-44.

15 Nur Zahidah Jaapar \& Raihanah Azahari, 'Model Keluarga Bahagia Menurut Islam,' 25-44.

16 Dollahite, David C. \& Lambert, Nathaniel M., 'Forsaking All Others: How Religious Involvement Promotes Marital Fidelity in Christian, Jewish, and Muslim Couples,' Review of Religious Research, 48/3 (2007): 290-307.

17 Robison, Linda C., 'Religious Orientation in Enduring Marriage: An Exploratory Study,' Review of Religious Research, 32/3 (1994): 207-217. 
Penghayatan Islam dan Hubungannya dengan Konflik Rumahtangga: Kajian di Unit Rundingcara, Bahagian Undang-Undang Keluarga, Jabatan Agama Islam Selangor

Brandt $^{18}$ pula menjelaskan penglibatan suami isteri dalam upacara keagamaan mampu untuk meningkatkan komitmen atau rasa tanggungjawab terhadap pasangan, meningkatkan kepuasan dalam perkahwinan sekali gus mengurangkan pertikaian yang boleh membawa kepada perceraian.

Goodman dan Dollahite ${ }^{19}$ yang menggunakan metode temu bual kepada 32 orang responden pertengahan umur yang telah mendirikan rumah tangga selama tempoh 20 tahun mendapati agama berpengaruh dalam perkahwinan melalui dua cara iaitu secara tidak langsung seperti melalui teologi atau kepercayaan terhadap doktrin dan juga secara langsung seperti memperkenankan doa, sebagai sumber kekuatan dan bimbingan serta adanya dosa bagi yang melakukan kesalahan.

Wolfinger ${ }^{20}$ turut menyatakan agama yang dianuti oleh seseorang mampu memandu mereka dalam menjalani kehidupan berkeluarga selagi mana ianya dijadikan rujukan utama dalam setiap tindakan yang diambil.

Nor Dalilah dan Raihanah ${ }^{21}$ pula mendapati tidak terdapat hubungan yang signifikan antara tahap pelaksanaan ibadat solat fardu dengan konflik rumah tangga walaupun dapatan kajian mendapati sebanyak 46\% responden mengakui pelaksanaan solat mereka berada pada tahap lemah dan antara faktor yang menyebabkan mereka meninggalkan solat adalah kerana sibuk dengan urusan harian yang mencatatkan peratusan tertinggi iaitu $38 \%$.

Butler $^{22}$ menunjukkan bahawa penyertaan bersama antara pasangan suami isteri dalam sembahyang mampu membina kerjasama yang baik antara suami isteri dan mengurangkan pertelingkahan lisan dalam penyelesaian masalah

18 Brandt, Sarah, 'Religious Homogamy and Marital Satisfaction: Couples that Pray Together, Stay Together,' (Student Paper, PSS Annual Meeting, October 2003), 11-20.

19 Goodman, Michael A. \& Dollahite, David C., 'How Religious Couples Perceive the Influence of God in Their Marriage,' Review of Religious Research, 48/2 (2006): 141-155.

20 Wolfinger, Nicholas H. \& Wilcox, W. Bradford, 'Happily Ever After? Religion, Marital Status, Gender and Relationship Quality in Urban Families,' Social Forces, 86/3 (March 2008): 1311-1337.

21 Nor Dalilah Zakaria \& Raihanah Azahari, 'Hubungan Antara Tahap Pelaksanaan Solat Fardu dengan Konflik Rumah Tangga: Kajian di Unit Rundingcara Keluarga (URK) Bahagian Perkahwinan,' Jurnal Syariah, 21/2 (2013): 145-164.

22 Butler, Mark H. et al., 'Prayer As A Conflict Resolution Ritual: Clinical Implications of Religious Couples,' The American Journal of Family Therapy, 30 (2002): 19-37. 
rumah tangga. Hunler ${ }^{23}$ pula menjelaskan kekerapan suami isteri hadir ke gereja telah mendekatkan mereka dengan tuhan sekali gus mampu mengawal emosi dan tingkah laku dalam menangani konflik rumah tangga. Petts ${ }^{24}$ mendapati pasangan suami isteri yang tidak mengamalkan ajaran agama lebih cenderung berlakunya konflik dalam rumah tangga mereka. Kajian ini juga membuktikan anak-anak dalam kalangan ibu bapa yang tidak mengamalkan ajaran agama lebih terdorong melibatkan diri dalam gejala sosial seperti mengambil dadah dan meminum arak jika dibandingkan dengan anak-anak yang mempunyai ibu bapa yang mengamalkan ajaran agama.

Norliza $^{25}$ mendapati mereka yang mempunyai ilmu agama yang mendalam dan mengamalkan penghayatan Islam dalam kehidupan seharian dapat memahami konsep atau tujuan sesebuah perkahwinan dengan baik. Sekali gus membawa kepada keharmonian rumah tangga dan pembentukan generasi muda yang beriman dan bertaqwa kepada Allah SWT. Jawiah ${ }^{26}$ pula menjelaskan antara asas yang digariskan dalam al-Quran dan al-Sunnah bagi mewujudkan institusi keluarga yang mantap ialah iman dan taqwa. Kepentingan kedua-dua unsur ini digambarkan dalam al-Quran sebagaimana kisah Luqman dalam pembentukan keluarganya yang menekankan aspek aqidah terlebih dahulu ${ }^{27}$ dan diikuti dengan pelaksanaan ibadat solat. ${ }^{28}$

23 Hunler, Olga S. \& Gencoz, Tulin, 'The Effect Of Religiousness On Marital Satisfaction: Testing Themediator Role of Marital Problem Solving Between Religiousness and Marital Satisfaction Relationship,' Contemporary Family Therapy, 27/1 (2005): 123-137.

24 Petts, Richard J. \& Knoester, Chris, 'Parents' Religious Heterogamy and Children's Well-Being,' Journal for the Scientific Study of Religion, 46/3 (2007): 373-389.

25 Norliza Ghazali, 'Objektif Perkahwinan: Satu Kajian Khusus Terhadap Kefahaman dan Penghayatan Masyarakat Islam di Kuala Lumpur,' (Disertasi Sarjana, Bahagian Pengajian Syariah, Akademi Pengajian Islam, Universiti Malaya, 1998), 253.

26 Jawiyah Dakir, 'Asas Pembentukan Keluarga Menurut Perspektif al-Qur'an dan al-Sunnah,' Islamiyyat, 17 (1996): 3-18.

27 Firman Allah SWT yang bermaksud: "Dan (ingatlah) ketika Luqman berkata kepada anaknya, semasa ia memberi nasihat kepadanya: 'Wahai anak kesayanganku, janganlah engkau mempersekutukan Allah (dengan sesuatu yang lain), sesungguhnya perbuatan syirik itu adalah satu kezaliman yang besar'.." (Surah Luqman, 31: 13).

28 Firman Allah SWT yang bermaksud: "Wahai anak kesayanganku, dirikanlah sembahyang, dan suruhlah berbuat kebaikan, serta laranglah daripada melakukan perbuatan yang mungkar, dan bersabarlah atas segala bala bencana yang menimpamu. Sesungguhnya yang demikian itu adalah dari perkara-perkara yang dikehendaki diambil berat melakukannya..." (Surah Luqman, 31: 17). 
Penghayatan Islam dan Hubungannya dengan Konflik Rumahtangga: Kajian di Unit Rundingcara, Bahagian Undang-Undang Keluarga, Jabatan Agama Islam Selangor

Begitu pun, realiti yang berlaku dalam masyarakat di Malaysia amnya dan di Selangor khasnya menunjukkan statistik perceraian dalam kalangan masyarakat Muslim semakin meningkat dari semasa ke semasa. Jabatan Kemajuan Islam Malaysia (JAKIM) melaporkan terdapat purata 70 kes perceraian dilaporkan sehari, 2,000 kes dilaporkan sebulan dan 25,000 kes setahun di seluruh negara bagi tahun 2011. ${ }^{29}$ Malah statistik JAKIM juga menunjukkan Selangor adalah negeri yang mencatatkan kes perceraian yang paling tinggi iaitu sebanyak 34,302 pasangan, diikuti Kelantan 20880 pasangan, Johor 19,946 pasangan serta Kedah sebanyak 18,954 pasangan. Jumlah-jumlah tersebut menunjukkan satu angka yang besar dalam tempoh sepuluh tahun iaitu dari tahun 2000 sehingga 2010. Terdapat dakwaan yang menyatakan, antara sebab berlakunya peningkatan kadar perceraian ialah kerana kebanyakkan individu yang mendirikan rumah tangga tidak memahami falsafah perkahwinan. Ia juga berpunca daripada ceteknya ilmu agama dan penghayatannya dalam kehidupan berumah tangga. ${ }^{30}$ Kenyataan ini juga disokong oleh Timbalan Menteri di Jabatan Perdana Menteri, Dato Dr Mashitah Ibrahim yang menyatakan, bahawa perceraian yang meningkat setiap tahun berpunca daripada kurangnya penghayatan agama dalam kalangan suami isteri termasuk pengabaian solat. ${ }^{31}$

Justeru, artikel ini cuba mengenal pasti tahap penghayatan Islam dalam kalangan suami isteri dan adakah konflik rumah tangga yang berlaku berpunca daripada penghayatan Islam yang lemah dalam kalangan mereka. Kajian ini memberi fokus kepada pasangan yang mendapatkan khidmat kaunseling di Unit Rundingcara, Bahagian Undang-Undang Keluarga, Jabatan Agama Islam Selangor.

\section{METODOLOGI KAJIAN}

Artikel ini dihasilkan berdasarkan kajian yang dilakukan di Unit Rundingcara, Bahagian Undang-undang Keluarga, Jabatan Agama Islam Selangor. Responden dipilih menggunakan kaedah persampelan bertujuan, melibatkan

29 Berita Harian, 'Tiga Kes Cerai dalam Satu Jam,' laman sesawang BH Online, http://www.bharian.com.my/bharian/articles/Tigakesceraidalam1jam/Article, dicapai 28 Disember 2013.

30 Berita Harian, 'Tiga Kes Cerai dalam Satu Jam,' laman sesawang BH Online, http://www.bharian.com.my/bharian/articles/Tigakesceraidalam1jam/Article, dicapai 28 Disember 2013.

31 Berita Harian, 'Satu Perceraian Setiap 15 Minit,' laman sesawang BH Online, http://www.bharian.com.my/bharian/articles/1 perceraiansetiap15minit_ Mashitah/Article/index_html, dicapai 28 Disember 2013. 
10 individu yang terdiri daripada salah satu pihak sahaja iaitu sama ada suami atau isteri dan bukan secara berpasangan yang telah hadir untuk kali kedua dan ke atas ke Unit Rundingcara, JAIS untuk mendapatkan khidmat nasihat antara bulan Mei-Jun 2014. Kaedah temu bual berstruktur dan tidak berstruktur digunakan untuk mengumpul maklumat daripada responden berdasarkan keseragaman soalan-soalan yang telah dibina.

Soalan temu bual dibahagikan kepada empat bahagian iaitu aqidah, ibadah, akhlak dan juga masalah rumah tangga. Aspek aqidah merangkumi soalan tentang kefahaman responden terhadap tujuan dan matlamat manusia hidup, pengetahuan responden terhadap akibat mengabaikan tanggungjawab sebagai suami/isteri, dan juga perasaan serta penerimaan mereka terhadap ujian Allah SWT. Aspek ibadah pula merangkumi solat fardu, solat sunat, solat berjemaah, solat jumaat, zakat, puasa Ramadhan, puasa sunat dan juga amalan membaca al-Quran. Aspek akhlak lebih memberi penekanan pada penutupan aurat, pergaulan dengan yang berlainan jantina dan juga sikap mereka dalam menyelesaikan sesuatu masalah iaitu sikap memaafkan, sikap sabar dan juga sikap terhadap teguran atau nasihat yang diberikan. Bagi permasalahan rumah tangga pula responden ditanya mengenai punca tercetusnya konflik dalam rumah tangga dan perkaitan dengan amalan ajaran Islam mereka.

Pembinaan soalan temu bual adalah merujuk kepada instrumen soal selidik dalam kajian-kajian lepas antaranya kajian The Short Muslims Practice and Belief Scale; ${ }^{32}$ iaitu pemilihan item penghayatan Islam adalah dalam aspek pengetahuan agama dan ibadah, kajian Kesahan dan Kebolehpercayaan Instrumen Penghayatan Akidah ${ }^{33}$ oleh Norsaleha Mohd Salleh dan rakan-rakan; kajian ini telah membahagikan penghayatan aqidah kepada tiga konstruk iaitu kefahaman, perasaan dan amalan. Konstruk yang diguna pakai dalam kajian ini adalah konstruk kefahaman berkaitan aqidah. Kajian Walijah Ahmad, ${ }^{34}$ dan Ahmad Sabri Osman ${ }^{35}$ pula dijadikan rujukan membina item penghayatan

32 AlMarri, Tayyiba S.K. et al., 'The Development of the Short Muslim Practice and Belief Scale,' Mental Health, Religion \& Culture, 12/5 (Julai 2009): 415-426.

33 Norsaleha Mohd. Salleh et al., 'Kesahan dan Kebolehpercayaan Instrumen Penghayatan Akidah,' International Journal of Islamic Thought, 3 (Jun 2013): 71-80.

34 Walijah Ahmad Jamburi, 'Penghayatan Ibadah dalam Kalangan Pelajar Islam: Kajian di Beberapa Buah Sekolah Menengah Kebangsaan di Petaling Jaya, Selangor,' (Disertasi Sarjana, Jabatan Fiqh dan Usul, Akademi Pengajian Islam, Universiti Malaya, 2010).

35 Ahmad Sabri Osman, 'Sistem Pendidikan Islam: Suatu Tentang Keberkesanan Penghayatannya di Kalangan Mahasiswa Universiti Teknologi Mara (UiTM) Kampus Arau, Perlis,' (Disertasi Sarjana, Jabatan Sejarah dan Tamadun Islam, Bahagian Pengajian Usuluddin, Akademi Pengajian Islam, 2002). 
Penghayatan Islam dan Hubungannya dengan Konflik Rumahtangga: Kajian di Unit Rundingcara, Bahagian Undang-Undang Keluarga, Jabatan Agama Islam Selangor

Islam dalam aspek ibadah manakala kajian Azma Mahmood ${ }^{36}$ pula menjadi rujukan dalam membina item dari aspek akhlak dan aqidah. Kesemua itemitem ini diubahsuai kepada bentuk soalan yang lebih lengkap dan terperinci mengikut ketepatan serta kesesuaian dengan kajian ini.

Sebaik sahaja temu bual selesai dijalankan, data yang diperoleh diulang dengar dan disalin ke dalam sebuah transkrip. Proses analisis data melibatkan tiga langkah iaitu pembersihan data (data reduction), pemaparan data (data display) serta kesimpulan dan pembuktian (conclusion drawing and verification). Pembersihan data merujuk kepada proses data diperiksa dan ditapis untuk menentukan sama ada ianya sesuai dengan tema yang telah ditetapkan dan pembuangan bagi data-data yang tidak berkaitan. Seterusnya langkah mempamerkan data iaitu proses di mana data-data dalam transkrip dipamerkan bagi tujuan membuat rumusan untuk mudah difahami. Petikan daripada sesi temu bual dijadikan sebagai rujukan untuk menyokong dan membuktikan kesahihan isu yang berkaitan. Manakala bahagian yang terakhir dalam aktiviti penganalisisan ini ialah melakarkan kesimpulan dan mengemukakan pembuktian. Ianya dilakukan dengan melihat kepada segala data yang telah dianalisis untuk mengemukakan kesimpulan bagi maklumat tersebut.

\section{DAPATAN DAN PERBINCANGAN}

\section{Profil Responden}

Jadual 1: Profil Responden

\begin{tabular}{ccccccc}
\hline Resp & Jantina & $\begin{array}{c}\text { Umur } \\
\text { (Tahun) }\end{array}$ & Pendidikan & $\begin{array}{c}\text { Tempoh } \\
\text { Perkahwinan } \\
\text { (Tahun) }\end{array}$ & Pekerjaan & $\begin{array}{c}\text { Pendapatan } \\
\text { Bulanan }\end{array}$ \\
\hline R1 & P & 29 & SPM & 2 & Pembantu Jualan & RM 2000 \\
R2 & P & 26 & SPM & 2 & Pentadbir & RM 900 \\
R3 & P & 28 & Sijil & 6 & $\begin{array}{c}\text { Pengurus Sumber } \\
\text { Manusia }\end{array}$ & RM 2500 \\
R4 & L & 27 & Sarjana Muda & 1 & Pembantu & RM 1500 \\
& & & PMR & 7 & Penyelidik & Kilang \\
R5 & P & 33 & RM 700 \\
\hline
\end{tabular}

36 Azma Mahmood, 'Pengukuran Tahap Penghayatan Pendidikan Islam PelajarPelajar Sekolah Menengah di Malaysia,' (Tesis Kedoktoran, Fakulti Pendidikan, Universiti Kebangsaan Malaysia, 2006). 


\begin{tabular}{|c|c|c|c|c|c|c|}
\hline Resp & Jantina & $\begin{array}{l}\text { Umur } \\
\text { (Tahun) }\end{array}$ & Pendidikan & $\begin{array}{c}\text { Tempoh } \\
\text { Perkahwinan } \\
\text { (Tahun) }\end{array}$ & Pekerjaan & $\begin{array}{c}\text { Pendapatan } \\
\text { Bulanan }\end{array}$ \\
\hline R5 & $\mathrm{P}$ & 33 & PMR & 7 & Kilang & RM 700 \\
\hline R6 & $\mathrm{L}$ & 29 & SPM & 4 & Pembantu Tadbir & RM 1700 \\
\hline R7 & $\mathrm{L}$ & 45 & SPM & 13 & $\begin{array}{c}\text { Electrical } \\
\text { Chargeman }\end{array}$ & RM $3000++$ \\
\hline $\mathrm{R} 8$ & $\mathrm{P}$ & 41 & Sarjana Muda & 13 & Berniaga & RM 750 \\
\hline R9 & $\mathrm{P}$ & 26 & Darjah 6 & 6 & Tidak bekerja & - \\
\hline $\mathrm{R} 10$ & $\mathrm{~L}$ & 36 & $\begin{array}{c}\text { Sijil } \\
\text { Politeknik }\end{array}$ & 9 & Kerja sendiri & RM 5000 \\
\hline
\end{tabular}

Sumber: Borang temu bual, 14 Mei-16 Jun 2014.

Jadual 1 menunjukkan bahawa tahap pendidikan paling rendah dalam kalangan responden adalah tamat sehingga darjah enam. Manakala lima daripada responden berpendidikan menengah iaitu empat daripadanya memiliki Sijil Peperiksaan Malaysia (SPM) dan seorang setakat Penilaian Menengah Rendah (PMR). Selebihnya pula iaitu dua orang responden berjaya menyambung pengajian mereka di peringkat sijil manakala dua orang lagi adalah pemegang Ijazah Sarjana Muda dari universiti awam.

Hasil analisis juga mendapati tempoh perkahwinan 1-10 tahun berisiko untuk berlakunya konflik rumah tangga kerana dapatan menunjukkan majoriti lapan orang responden mengalami konflik rumah tangga dalam tempoh tersebut. Dapatan kajian juga mendapati sembilan daripada sepuluh orang responden mempunyai pekerjaan manakala seorang lagi suri rumah iaitu tidak bekerja. Daripada sembilan orang responden yang bekerja, lapan dari mereka mempunyai pendapatan bawah RM3000, manakala selebihnya iaitu setiap seorang daripada responden berpendapatan sebanyak RM3001 hingga RM4000 dan RM4001 sehingga RM5000. Ini menunjukkan bahawa mereka yang terlibat dalam konflik rumah tangga mempunyai saiz pendapatan yang sederhana.

\section{Analisis Tahap Penghayatan Islam}

\section{a) Penghayatan Akidah}

\section{(i) Matlamat Hidup Manusia}

Berkaitan dengan perkara pokok dalam akidah Islam iaitu pengetahuan responden terhadap matlamat manusia hidup di atas muka bumi ini, kajian 
Penghayatan Islam dan Hubungannya dengan Konflik Rumahtangga: Kajian di Unit Rundingcara, Bahagian Undang-Undang Keluarga, Jabatan Agama Islam Selangor

mendapati majoriti sembilan responden faham dan mengetahui akan hal tersebut manakala seorang lagi responden menyatakan tidak mengetahuinya.

Majoriti responden berpendapat tujuan utama manusia hidup di atas muka bumi ini ialah untuk beribadat dan mengabdikan diri kepada Allah SWT. Manusia juga mempunyai tanggungjawab sebagai khalifah dan wajib mematuhi segala perintah Allah SWT yang terdapat dalam al-Quran dan as-Sunnah serta melakukan sesuatu hanya semata-mata kerana Allah SWT. Sebagaimana yang dijelaskan oleh responden:

"Hidup kita untuk beribadat kepada Allah..semua benda kita buat kerana Allah. akhirnya kita mati, mati cara baik apa semua..akhir sekali syurga la.." (R: 4)

"Sebenarnya kita ni..untuk kita jadi hamba la..bila hamba tu, benda yang kita kena patuh yang ada dalam al-Qur'an asSunnah..”(R: 10)

“......kita ada dua tugas..sebagai hamba dan juga sebagai khalifah..bagi saya macam tu.. bila saya jadi khalifah, saya kena buat baik pada orang, tunjuk tauladan pada orang, saya kena bagitahu orang bukan muslim supaya masuk muslim [Islam].. terangkan Islam pada semua orang.. bagitahu tentang kebaikan.."(R: 7)

\section{(ii) Hukum Pengabaian Tanggungjawab}

Seterusnya, tahap pengetahuan akidah responden diuji dengan pengetahuan mereka terhadap hukum pengabaian tanggungjawab terhadap pasangan. Hasil kajian mendapati, kesemua responden mengetahui akibat pengabaian tanggungjawab sebagai seorang suami atau isteri adalah berdosa besar. Mereka menyatakan pengabaian tanggungjawab ini merupakan antara perkara yang dimurkai oleh Allah SWT kerana tanggungjawab terhadap suami/ isteri serta keluarga merupakan satu amanah dari Allah SWT yang wajib dilaksanakan dengan baik setelah berlakunya akad perkahwinan sepertimana yang dinyatakan oleh responden ketujuh:

“...Allah bagi tanggungjawab kepada kita untuk menjaga isteri dan anak-anak.. tu tanggungjawab yang paling besar..amanah Allah supaya menjaga isteri dan anak..kalau kita abaikan amanah yang Allah bagi, Allah akan murka kepada kita..kita melakukan satu dosa yang paling besar sebab ianya amanah.. 
amanah ni satu benda yang sangat besar, yang merupakan satu beban.." (R: 7)

\section{(iii) Masalah Rumah Tangga Sebagai Ujian Allah SWT}

Hasil daripada temu bual mendapati, kesemua sepuluh orang responden bersetuju dan beranggapan masalah rumah tangga yang dihadapi merupakan ujian dari Allah SWT. Mereka berpendapat ujian yang Allah SWT turunkan ini adalah untuk menguji tahap kesabaran dan sebagai balasan atas dosadosa silam. Mereka juga memahami dan yakin bahawa apa yang berlaku ini merupakan qada dan qadar Allah SWT serta perancangan Allah SWT untuk hamba-Nya. Malah mereka menemui hikmah disebalik apa yang berlaku kerana ujian ini menjadikan mereka lebih dekat dengan Allah SWT dan lebih berminat mendalami ilmu agama.

"Sesungguhnya saya rasa bersyukur la sebab Allah pilih saya.. sebab dulu saya tak pandai mengaji, sekarang saya pandai mengaji.yang sambung-sambung ayat tu kan.dulu saya tak tahu al-Qursi tu ayat mana..dulu tahu al-Fatihah, tiga Qul atau surahsurah lazim yang pendek-pendek tu saja.."(R: 8)

\section{(iv) Penerimaan Responden Terhadap Ujian Allah SWT}

Lanjutan daripada persoalan di atas, responden ditanya mengenai penerimaan mereka terhadap ujian Allah SWT. Hasil analisis mendapati lima orang responden menyatakan mereka menerima ujian Allah SWT ini dengan redha dan hati terbuka. Mereka pasrahkan segala yang berlaku kepada Allah SWT dan menjadikan sikap pasrah dengan ketentuan Allah SWT ini sebagai pedoman hidup di dunia ini. Mereka juga redha kerana merasakan perancangan Allah SWT adalah yang terbaik untuk mereka. Sebagaimana yang dinyatakan oleh responden:

"Sabar, ikhlas dan pasrah kepada yang Maha Esa..sebab itu saya menangis dalam hati dengan sebut nama Allah..saya pasrahkan semuanya kepada Allah..rezeki jodoh saya pasrahkan kepada Allah.itulah pedoman hidup dalam dunia.."(R: 1)

"Alhamdulillah saya redha la..saya sangat redha..saya rasa rancangan Allah tu yang terbaik..” ( $R: 8)$

Namun bagi mereka yang tidak dapat menerima ujian Allah SWT dengan hati yang redha menyatakan mereka merasakan dugaan yang melanda terlalu berat serta tidak mampu untuk menanggungnya. Tetapi setelah bermuhasabah 
Penghayatan Islam dan Hubungannya dengan Konflik Rumahtangga: Kajian di Unit Rundingcara, Bahagian Undang-Undang Keluarga, Jabatan Agama Islam Selangor

diri dan memujuk hati, kerelaan hati itu hadir dan mereka dapat berfikir secara positif dan rasional. Sebagaimana yang dinyatakan oleh responden:

"Sebelum ni tak boleh terima la..macam takut....macam terfikir kenapa diuji dengan ujian macam ni..tapi sekarang ni muhasabah diri, saya dah terima balik lah semuanya..sabar.. ”(R: 4)

"Saya tak tahu nak cakap macam mana..tapi saya memang ada yang benci dengan diri sendiri la..kenapa tuhan uji saya macam ni..kenapa..apa salah saya..sebab saya memang tertekan dengan dia..memang tak larat la..saya pernah fikir mati mungkin lebih baik kot daripada hidup.."(R: 2)

\section{b) Penghayatan Ibadah}

\section{(i) Solat Fardu}

Hasil kajian mendapati majoriti responden iaitu sebanyak tujuh orang responden menyatakan mereka tidak menunaikan solat fardu secara konsisten iaitu tidak cukup lima waktu sehari semalam. Mereka mengakui hanya solat tiga atau empat waktu dalam sehari. Manakala tiga lagi responden menyatakan perlaksanaan solat fardu mereka adalah sempurna. Ini menunjukkan bahawa perlaksanaan solat fardu suami isteri yang berkonflik di Selangor berada pada tahap yang lemah. Dapatan kajian ini mengukuhkan lagi hasil kajian Nor Dalilah $^{37}$ yang mendapati perlaksanaan solat fardu suami isteri yang berkonflik berada pada tahap yang sama.

Dari aspek waktu solat yang sering ditinggalkan pula, hasil analisis mendapati solat Subuh mencatatkan jumlah tertinggi di mana lima orang responden sering meninggalkan solat tersebut. Kemudian diikuti dengan solat Maghrib dan Isyak yang mencatatkan jumlah kedua tertinggi dengan kedua-duanya mencatatkan dua orang responden. Manakala solat Zohor pula sering ditinggalkan oleh seorang responden dan tiada responden yang sering meninggalkan solat Asar.

Antara sebab yang dikenalpasti mereka meninggalkan solat fardu ialah sukar untuk bangun pagi dan juga kesuntukan masa. Responden menjelaskan:

“...kadang-kadang kita keletihan kan..macam tak sedar..kadang kunci jam, jam tak berbunyi..hah macam tu la..” (R:3)

37 Nor Dalilah Zakaria \& Raihanah Azahari, 'Hubungan Antara Tahap Pelaksanaan Solat Fardu dengan Konflik Rumah Tangga: Kajian di Unit Rundingcara Keluarga (URK) Bahagian Perkahwinan,' 145-164. 
"Sebab kerja lah..rehat ok la..kadang-kadang kita makan nak kena beratur lagi kan..nak solat la..dah tertinggal masa banyak. sebab solat dia tak boleh kelam kabut sangat.." (R: 1)

\section{(ii) Solat Sunat}

Hasil kajian mendapati hanya seorang responden selalu menunaikan solat sunat, lima orang responden kadang-kadang menunaikan solat sunat, manakala selebihnya iaitu empat orang tidak pernah menunaikan solat sunat. Responden yang menunaikan solat sunat kadang-kadang menyatakan mereka menunaikan solat sunat apabila ada kesempatan seperti bangun awal pagi dan sampai awal ditempat kerja sepertimana yang dinyatakan oleh responden keempat dan kesepuluh:

"Solat sunat, kadang saya bangun subuh awal kan, dulu saya kerja kat Ampang..kadang 5.30 saya bangun, so nak tunggu subuh, mandi siap-siap, saya tahajjud la sekali..solat taubat.." (R: 4)

Bagi lima orang responden lagi yang tidak pernah menunaikan solat sunat menjelaskan mereka tidak menunaikan solat sunat kerana kesibukan menguruskan anak serta tidak mengetahui cara untuk melakukannya sebagaimana yang dinyatakan oleh responden:

"Memang saya tak tahu la solat-solat sunat..tak tahu cara nak buat.." (R: 5)

\section{(iii) Solat Jamaah}

Hasil analisis mendapati empat orang responden kadang-kadang menunaikan solat jamaah bersama dengan keluarga, dua orang responden pernah hanya sekali dua sahaja menunaikan solat jemaah bersama keluarga dan selebihnya lima orang tidak pernah menunaikan solat jamaah sepanjang perkahwinan mereka. Dapatan kajian ini menunjukkan bahawa solat jamaah dalam kalangan suami isteri tidak menjadi amalan yang dipraktikkan dalam kehidupan berkeluarga mereka. Dapatan ini menyokong kajian Sapinah Mat Salleh ${ }^{38}$

\footnotetext{
38 Sapinah Mat Salleh, 'Institusi Kekeluargaan Islam: Pemahaman dan Pengamalan dalam Konteks Kekeluargaan Masa Kini dan Peranannya ke Arah Pembentukan Keluarga Bahagia: Tinjauan Khusus Di Wilayah Persekutuan Kuala Lumpur,' (Latihan Ilmiah, Jabatan Pengajian Islam, Fakulti Sastera dan Sains Sosial, Universiti Malaya, 1995/1996).
} 
Penghayatan Islam dan Hubungannya dengan Konflik Rumahtangga: Kajian di Unit Rundingcara, Bahagian Undang-Undang Keluarga, Jabatan Agama Islam Selangor

yang mendapati kebanyakkan masyarakat sekarang semakin mengabaikan sembahyang berjamaah bersama ahli keluarga atas alasan tiada masa.

Hasil kajian juga mendapati antara faktor responden tidak pernah menunaikan solat secara berjamaah kerana mereka bergilir-gilir menjaga anak untuk bersolat dan keengganan pasangan untuk solat bersama-sama seperti yang dinyatakan oleh responden:

"Sebabkan anak..saya sembahyang dulu, kemudian baru dia sembahyang..so tengok la..kadang dia sembahyang, saya jaga anak..so kadang macam tu la....” (R: 10)

"Pernah ajak..tapi dia macam tak suka..dia cakap hari ni aku buat, nanti esok-esok aku tak buat.takkan aku nak buat sebab kau.."(R: 9)

\section{(iv) Solat Jumaat}

Hasil kajian mendapati dua orang daripada empat responden lelaki yang dikaji tidak pernah meninggalkan solat Jumaat. Manakala dua lagi responden lelaki pernah meninggalkan solat Jumaat atas alasan hal peribadi dan juga kerja sebagaimana yang dinyatakan oleh responden:

"Ada dalam seminggu tu tak hadir ada jugak..kiranya dalam 4 minggu sekali saja la macam tu..sebab yang miss tu, sebab ambil anak macam tu la..kerja ada jugak..kadang outstation ke apa.." (R: 6)

"Masa saya kerja syif, memang tak boleh solat jumaat..sebab kerja la..sebab ada fatwa kata kalau kerja tak apa tak solat jumaat.y yang tak ada masalah saya pergi la.. sebab saya kerja plan dulu..memang tak boleh keluar la..plan 24 jam memang kena ada orang jaga la..orang syif memang tak boleh tinggalkan plan.."(R: 4)

\section{(v) Puasa Wajib}

Kajian mendapati majoriti sembilan responden berjaya melaksanakan ibadah puasa Ramadhan dengan sempurna setiap tahun. Manakala seorang lagi responden mengakui tidak dapat berpuasa penuh pada bulan Ramadhan kerana penyakit gastrik yang dialami menyebabkan perutnya tidak tahan sekiranya tidak makan dan minum dalam jangka masa yang panjang serta mengakibatkan muntah ketika berbuka. Keadaan ini menyebabkannya hanya mampu berpuasa 
selama empat jam sahaja. Hal ini seperti yang dijelaskan oleh responden kedua iaitu:

"Saya boleh sampai petang..tapi masa buka puasa tu, saya minum saya pergi muntah..sebab macam ada gastrik kan..sebab itu saya susah la..tapi saya cuba la..saya pergi buka puasa saya muntah.. saya makan pun saya muntah..macam tu jadi.. saya macam cuba juga tapi saya tak boleh..tapi saya cuma buat empat jam sahaja.. kemudian itu saya memang tak boleh..memang tak cukup..saya tak boleh.." (R: 9)

\section{(vi) Puasa Sunat}

Secara umumnya, kajian mendapati kesemua sepuluh responden tidak menjadikan puasa sunat sebagai amalan mereka. Ini kerana tiga orang daripada mereka kadang-kadang melaksanakan puasa sunat, empat orang jarang melakukan puasa sunat dan tiga orang responden tidak pernah melakukan puasa sunat.

Bagi responden yang jarang dan tidak pernah melakukan puasa sunat menjelaskan antara sebab mereka tidak berpuasa sunat adalah kerana nafsu makan yang tinggi dan beranggapan tidak perlu melakukan puasa sunat seandainya solat yang wajib pun tidak dilakukan dengan sempurna sepertimana yang dinyatakan oleh responden:

"Sunnat jarang..nafsu tinggi nak makan kan..kadang-kadang boleh tahan..kadang-kadang tak boleh langsung..hah macam tu.. buat tu buat..tapi kena khayalkan diri la..kena sibukkan diri biar tak terasa la..”(R: 6)

"Puasa sunat tu jarang la..saya tak ambil puasa sunat la sebab.. sebab solat yang wajib ni saya tinggalkan..saya fikir kat situ saja..so kalau puasa sunat memang saya tak amalkan..kalau yang lima waktu yang wajib pun saya tinggal..tu saja yang saya fikir.." (R: 1)

\section{(vii) Zakat}

Bagi kefarduan zakat fitrah, kesemua sepuluh orang responden berjaya melaksanakan kewajipan ini dengan sempurna dan membayarnya dalam tempoh masa yang telah ditetapkan. Hasil kajian juga mendapati hanya dua orang responden yang berkewajipan mengeluarkan zakat pendapatan. Ini kerana gaji mereka memenuhi syarat nisab zakat pendapatan yang telah 
Penghayatan Islam dan Hubungannya dengan Konflik Rumahtangga: Kajian di Unit Rundingcara, Bahagian Undang-Undang Keluarga, Jabatan Agama Islam Selangor

disyariatkan. Mereka menggunakan kaedah pembayaran bulanan dengan potongan daripada gaji setiap bulan. Responden kesepuluh menjelaskan:

"Zakat pendapatan..gaji saya tu tiap-tiap bulan saya ni ke majlis zakat Selangor la..yang tu memang saya potong tiap-tiap bulan daripada CIMB klik..slip-slip semua tu..saya simpan slip tu..” (R: 10)

\section{(viii) Membaca al-Quran}

Hasil analisis mendapati hanya seorang responden menjadikan pembacaan alQuran sebagai amalan harian, manakala lima orang responden membaca alQuran sekali seminggu dan empat lagi responden mengakui jarang membaca al-Quran. Hasil kajian ini dilihat menyamai kajian Walijah Ahmad Jamburi39 yang mendapati responden yang jarang membaca al-Quran dan hanya membacanya seminggu sekali mencatatkan peratusan yang tinggi berbanding dengan yang membacanya setiap hari.

Bagi lima orang responden yang membaca al-Quran sekali seminggu menyatakan hanya membaca al-Quran pada hari Khamis malam Jumaat sahaja iaitu membaca surah Yassin dan surah al-Khafi. Pada hari-hari lain, mereka tidak membudayakan pembacaan al-Quran dalam kehidupan seharian. Ini seperti yang dinyatakan oleh responden keempat:

"Khamis malam tu memang baca, surah al-kahfi..hari-hari lain tu depends..tapi kalau kata quran tu memang kurang la..kategori memang kurang la.." (R: 4)

Hasil temu bual mendapati antara alasan yang diberikan oleh responden yang tidak menjadikan pembacaan al-Quran sebagai amalan harian adalah disebabkan sibuk dengan urusan harian dan juga waktu kerja yang tidak menentu sebagaimana yang dinyatakan oleh responden:

"Sebabnya bukan tak boleh baca, boleh..tapi mungkin masa kot.. masa macam terkejar-kejar.dengan anak yang baru nak besar. macam buas..kejap-kejap panggil..keadaan keliling..sebab duduk rumah dengan mak dengan adik beradik.jadi macam masa tu agak, nak uruskan sana nak uruskan sini, macam terkejar-kejar. sampai tak boleh nak uruskan masa untuk diri sendiri.."(R: 9)

39 Walijah, 'Penghayatan Ibadah.' 


\section{c) Penghayatan Akhlak}

\section{(i) Penutupan Aurat}

Adalah, didapati majoriti enam responden belum sempurna penutupan aurat mereka. Tidak sempurna di sini bermaksud tidak menutup aurat sebagaimana yang telah ditetapkan oleh Syarak iaitu menutup seluruh anggota tubuh melainkan muka dan tapak tangan bagi wanita dan dari pusat hingga ke lutut bagi lelaki. Manakala empat lagi responden pula menyatakan mereka telah menutup aurat dengan sempurna.

Hasil kajian juga mendapati terdapat segelintir responden wanita hanya menjaga aurat ketika berada di luar rumah, namun tidak ketika berada bersama dengan ahli keluarga yang bukan mahram mereka seperti ipar duai dan sepupu lelaki. Malah ada dalam kalangan mereka menyatakan tidak mengetahui kewajipan menutup aurat ketika berada bersama dengan ipar duai lelaki. Sebagaimana yang dinyatakan oleh responden:

"Macam biasa saja la..saya memang tak bertudung la..family dia pun kakak dia semua tak buat macam bertudung la..baju macam biasa la kita pakai yang menutup la..”(R: 3)

"Oh dulu sebab tak tahu kan.. kita kat kampung buka tudung la.. masa tu saya tak tahu..lepas tu bila saya dah problem macam ni kan, saya pergi berniaga dekat masjid-masjid, diorang jual yang mahram lelaki mahram perempuan tu, saya nampak la..oooo.. lepas tu ustazah dekat tv pun cakap tak boleh salam ipar duai kan..baru saya tahu..dulu saya salam juga la..macam abang ipar kan..saya salam juga la...."(R: 8)

Bagi responden lelaki pula, majoriti tiga responden menyatakan mereka telah menutup aurat dengan sempurna walaupun ketika bersukan. Namun terdapat seorang responden lelaki yang mengakui penutupan auratnya tidak sempurna lebih-lebih lagi ketika bersukan sebagaimana yang dijelaskan oleh responden keenam:

"Sempurna tu tak sangat la..main bola saja..kadang-kadang pakai tight dalam kadang tak pakai la..time sukan.."(R: 6)

\section{(ii) Adab Pergaulan Berlainan Jantina}

Secara umumnya, kajian mendapati kesemua sepuluh responden menjaga adab pergaulan mereka dengan rakan yang berlainan jantina. Terdapat responden yang memang tidak berminat bergaul atau berkawan dengan berlainan jantina. 
Malah dalam pemilihan kawan yang sama jantina juga, mereka mengambil langkah berhati-hati dan memilih kawan. Sebagaimana yang dinyatakan oleh responden pertama:

"Tak..saya memang tak minat bergaul dengan lelaki..saya suka bergaul dengan perempuan yang ada ciri-ciri agama la..yang ok la..akhlak dia..tengok la perangai dia macam mana..dia akhlak ok saya gaul dengan dia..ada setengah orang yang mana yang pakai tudung ni cakap-cakap benda yang tidak elok, hah saya tak gaul dengan orang macam tu.. "(R: 1)

\section{(iii) Sifat Pemaaf}

Hasil temu bual mendapati majoriti enam responden mudah memberi kemaafan pada orang yang melakukan kesalahan dengan mereka. Sifat ini didorong oleh sikap belas ihsan serta sikap tidak suka berdendam dan bergaduh dengan orang lain sebagaimana yang dijelaskan oleh responden:

“..sangat mudah [memaafkan]..senang kesian kat orang.. ” (R: 9)

“..saya tak suka buat gaduh dengan orang..cari pasal dengan orang..tak suka..biar orang tak suka saya..saya jarang tak suka orang.."(R: 4)

Tiga lagi responden pula menyatakan mereka memberi kemaafan berdasarkan kepada keadaan serta kesalahan yang dilakukan dan juga kemaafan diberikan untuk kesalahan pertama sahaja seperti yang dinyatakan oleh responden ketiga dan keenam iaitu:

"Emm saya tengok pada keadaan la..saya mudah nak memaafkan orang tapi saya tengok keadaan, situasi.. Kalau kita cakap berkali-kali kita cakap kita bincang dia tak nak buat tak nak ikut, tu kadang-kadang saya rasa macam tak nak maafkan dia.. ”(R: 3)

"Saya senang nak maafkan tapi jangan buat lagi la..kali kedua tak boleh la..sebab dah tahu jangan la buat lagi.." (R: 6)

Sikap ini tidak dikategorikan sebagai akhlak kerana istilah akhlak merupakan gambaran atau perihal keadaan jiwa manusia yang sudah sebati dalam diri yang muncul secara mudah dan senang tanpa perlu kepada pertimbangan atau niat tertentu. ${ }^{40}$

40 Zakaria Stapa, Akidah dan Akhlak dalam Kehidupan Muslim (Kuala Lumpur: Utusan Pulications \& Distributors, 1999), 21-22. 


\section{(iv) Sifat Sabar}

Sifat sabar ini dinilai dengan mengetahui cara serta sikap responden dalam menangani situasi yang menyakitkan hati serta menimbulkan kemarahan mereka. Seorang yang sabar akan menghadapi kemarahan dengan ketenangan hati tanpa cepat melatah serta terpengaruh dengan keadaan. Dapatan menunjukkan enam daripada responden lebih suka mengambil sikap berdiam diri apabila berhadapan dengan situasi yang tegang. Manakala empat lagi responden mengakui mereka mempunyai sikap kurang sabar dan cepat marah. Bagi yang mengambil sikap berdiam diri menyatakan, diam mereka adalah disebabkan tidak mahu mewujudkan situasi lebih teruk seperti bergaduh dan sebagainya. Seperti yang dinyatakan oleh responden kesembilan:

"Selalunya saya akan diam..kalau dia sakitkan hati saya, saya diam..sebab kalau cakap jadi gaduh kan..baik saya diam..saya rasa macam tu jalan terbaik..kiranya saya pendam sendiri la..”(R: 9)

Malah diam mereka adalah untuk berfikir dengan lebih tenang dan baik agar tindakan yang wajar boleh diambil bagi menangani situasi tersebut sepertimana yang dinyatakan oleh responden keenam:

"Setakat ni saya memang senyap saja la..katakan kalau macam saya terasa tu, terasa jugak la tapi tak apa saya senyap..saya tengok apa tindakan yang perlu saya buat..tapi tak ada la sampai saya naik tangan ke tak ada la..saya akan cakap saja la.. "(R: 6)

Situasi ini memberi gambaran bahawa ketenangan yang dirasai oleh seseorang boleh memberi impak kepada keputusan yang dibuat. Keputusan yang dibuat oleh seseorang dalam keadaan marah adalah keputusan yang dibuat tanpa pertimbangan akal yang baik dan waras dan ianya lebih menjurus kepada mengikut hawa nafsu.

Responden yang mengakui cepat marah pula menyatakan sekiranya berlaku perkara yang menyakitkan hati, mereka lebih senang untuk terus marah dari berdiam diri. Ini menunjukkan mereka kurang sabar dalam menyelesaikan masalah dengan cara yang terbaik. Responden kesepuluh menjelaskan:

"Biasa mula-mula saya marah la..pasal saya bukan jenis menyimpan..kalau saya marah, saya lepas kan..tu saja..saya tak nakfikir balik..tu saja..sebab tu bila saya lepas, sampai satu limit saya nak melampaui, saya keluar.." (R: 10) 
Penghayatan Islam dan Hubungannya dengan Konflik Rumahtangga: Kajian di Unit Rundingcara, Bahagian Undang-Undang Keluarga, Jabatan Agama Islam Selangor

\section{(v) Sikap Keterbukaan}

Sikap keterbukaan ialah sikap yang boleh dinilai berdasarkan reaksi responden terhadap teguran atau nasihat dari orang lain. Hasil analisis mendapati majoriti tujuh orang responden adalah seorang yang boleh menerima kritikan serta nasihat. Mereka akan mengakui kesalahan dan memperbetul serta memperbaikinya sekiranya perkara tersebut dirasakan betul sebagaimana yang dinyatakan oleh responden:

"Macam siapa-siapa tegur pun saya akan cakap ok terima kasih.. saya akan cuba fikir betul ke tak yang dia orang tegur tu..kalau betul saya akan cuba buat, saya akan cuba betulkan kesalahan tu.." $(R: 9)$

Manakala tiga lagi responden mengakui tidak mudah untuk menerima nasihat serta teguran orang lain menyatakan, mereka selalunya akan memberi reaksi negatif seperti menarik muka masam apabila ditegur dan memerlukan masa untuk menerimanya sepertimana yang dijelaskan oleh responden:

"Tarik muka masam..muka masam..kalau dah lama tu baru ok sikit..boleh terima.. makan masa juga la..” (R: 5)

\section{Penghayatan Islam dan Konflik Rumah Tangga}

Hasil analisis mendapati kebanyakkan pasangan yang berkonflik mempunyai masalah dengan sikap diri sendiri. Terdapat dalam kalangan suami isteri yang berkonflik berjaya melaksanakan kewajipan ibadah dengan baik, namun disebabkan sikap diri yang cepat marah, keras hati dan kuat cemburu menyebabkan berlakunya pergaduhan yang besar dalam rumah tangga mereka. Sebagaimana yang dinyatakan oleh responden

"Kurang sabar.dengan pemarah sikit la..tidak boleh terima hakikat.." (R: 4)

"Saya keras hati la..saya macam buat tidak tahu macam itu la.. macam ok tak apa la..macam tidak ambil tahu la..macam keras hati la..orang dah buat begini pun macam relax je.. ” (R: 6)

"Saya ni memang cepat cemburu..cemburu yang teramat sangat la.. suami saya ni pula suka berkawan dengan perempuan.. bila suami saya dengan perempuan lain memang saya cemburu..." (R: 3) 
Ini menunjukkan bahawa penghayatan akidah dan ibadah yang dilakukan tidak dapat membentuk akhlak yang mulia dalam diri pengamalnya, sedangkan konsep asas dalam Islam adalah, akhlak mulia terhasil daripada pegangan akidah dan pelaksanaan Syariah Islam yang sempurna. Dapatan ini menyokong kajian Jamilah Manap ${ }^{41}$ yang menunjukkan akhlak individu mempunyai hubungan yang signifikan dengan akidah atau tahap keimanan seseorang.

Hal ini juga turut disokong dengan pendapat responden yang menyatakan bahawa penghayatan Islam mampu menjadi benteng dari berlakunya konflik rumah tangga yang serius. Ini sekiranya pelaksanaan ajaran Islam mampu mengekang diri individu daripada berakhlak dengan akhlak yang tidak baik. Namun sekiranya perlaksanaan ajaran Islam tidak memberi kesan pada diri individu, maka konflik rumah tangga yang serius tetap akan berlaku juga sepertimana yang dijelaskan oleh responden kesepuluh:

“ ......agama itu satu, satu lagi itu sikap diri..sikap-sikap diri.. kadang sikap diri tu, kalau didikan agama yang kuat boleh, orang kata mengekang sikap diri, dia kurang berlaku [konflik].. tapi kadang dia dua..kadang sikap diri dan agama, keperluan agama itu kita buat..kadang sikap diri kita buat tu, lebih kepada sikap.." (R: 10)

Selain dari sikap diri sendiri, hasil kajian juga mendapati majoriti responden mempunyai masalah dengan sikap pasangan mereka. Antara sikap yang tidak baik menurut pandangan responden terhadap pasangan mereka ialah suka berjudi, pukul isteri, menganiayai isteri, mengamalkan ilmu hitam dan minum arak. Sebagaimana yang dinyatakan oleh responden:

“...Tak bertanggungjawab..sambung ayam ...dia beli no ekor...” $(R: 1)$

"Dia kaki perempuan, minum arak, hisap rokok... sampai satu tahap, sebab tu saya minta tuntutan cerai..sebab bulan puasa, siang-siang saya tengah puasa, dia suruh saya minum arak.. tu yang buat saya rasa tidak boleh nak teruskan..bila saya bertudung, dia tidak suka..bila cakap pasal agama, dia tidak suka.. tu yang saya buat permohonan cerai..” (R: 9)

"Dia suka menganiyai saya la..menganiayai saya tu macam, dia berhutang..dia blacklist..jadi nama dia dalam Bank Negara memang rekod la..dah tidak boleh..jadi dia menggunakan

41 Jamiah Manap et al., 'Prinsip Pengukuran Religiositi dan Personaliti Muslim,' Journal of Psychology \& Human Development, 36/1 (2013): 36-43. 
Penghayatan Islam dan Hubungannya dengan Konflik Rumahtangga: Kajian di Unit Rundingcara, Bahagian Undang-Undang Keluarga, Jabatan Agama Islam Selangor

kesempatan yang saya ada...saya sanggup sampai saya gadai barang kemas saya..tapi tu bukan atas saya rela.. saya janji dengan dia nanti bayar balik..tapi bila gadai, sampai sekarang dah 6 tahun, dia tak ganti-ganti..." (R: 3)

Kajian juga mengenal pasti, antara sifat positif yang perlu ditanam dalam diri ialah sikap keterbukaan, merendah diri, bertolak ansur dan saling mengamalkan teknik komunikasi yang berkesan. Sifat positif ini mampu membantu mereka dalam menyelesaikan sesuatu masalah dengan baik. Sebagaimana yang dinyatakan oleh responden:

1) Komunikasi serta sikap keterbukaan penting dalam menghadapi konflik rumah tangga. Komunikasi dua hala perlu bagi membolehkan suami isteri berbincang, sekali gus menemui titik penyelesaian bagi masalah mereka. Dalam perbincangan tersebut, kedua pihak harus mempunyai sifat keterbukaan untuk menerima teguran dan mengakui kesalahan masingmasing. Hal ini dinyatakan oleh responden keempat dan ketiga iaitu:

"Kena sit down sama..yang salah mengaku salah.. yakinkan yang kita hendak berubah..apa-apa pun kena sama-sama lapang hati lapang dada cuba percaya..terima la dengan hati terbuka..”(R: 4)

2) Seorang lagi responden pula berpendapat sikap merendah diri dan give and take perlu dalam rumah tangga. Suami isteri perlu tahu kehendak pasangan masing-masing bagi membolehkan mereka memahami antara satu sama lain.

"Bagi saya benda ini tidak ada masalah kalau kita sendiri sesama kita ini bersikap orang kata merendah diri... maksudnya dia dapat terima apa yang kita hendak, kita pun boleh ikut apa yang dia hendak..dia tak boleh macam kita memberi sahaja... kita tak nak..dia nak terima je..tak boleh la macam tu... kena take and give...benda ni kena ada persefahaman.."(R: 3)

Hal ini juga turut dikukuhkan dengan kajian Norhayati Hamzah ${ }^{42}$ yang menyatakan pentingnya kedua suami isteri memiliki sifat positif bagi mengelak berlakunya konflik dalam rumah tangga. Antaranya mengamalkan teknik komunikasi yang baik dalam pergaulan suami isteri. Begitu juga dengan bersikap terbuka dan bersedia menerima teguran atau pandangan

42 Norhayati Hamzah, 'Menangani Konflik Institusi Perkahwinan: Analisisi dan Pandangan Al-Qur'an,' 13-15. 
Hasil temu bual juga mendapati lapan daripada sepuluh responden tidak menunaikan tanggungjawab dalam rumah tangga. Antara tanggungjawab yang sering gagal ditunaikan ialah memberi nafkah zahir dan batin. Sebagaimana yang dinyatakan oleh responden:

"Nafkah anak dia tidak bagi..sejak saya mengandung 2 bulan sampai sekarang, nafkah anak-anak dia tidak pernah bagi..masa kat Serawak, tidak pernah bagi nafkah anak-anak.duit belanja dapur semua saya sendiri yang kerja..masa dekat Serawak saya kerja..saya tanggung diri saya sendiri la..” (R:5)

"Masalah seksual..seksual saya kurang..macam [jaga] anak saya 24 jam.. terlalu letihkan malam..suami tidak tunaikan tanggungjawab dia macam nafkah dia tak bagi..kasih sayang saya macam berkuranganla..kedua badan saya tidak boleh terima..badan saya macam terlalu lemas sangat.." (R:1)

Ini selari dengan hasil analisis Unit Rundingcara, Jabatan Agama Islam Selangor dari tahun 2010-2013 yang menunjukkan masalah tidak bertanggungjawab mencatatkan jumlah tertinggi yang sering diadukan oleh klien selama lima tahun berturut-turut. Sekali gus ianya memberi gambaran bahawa tidak menunaikan tanggungjawab sebagai suami atau isteri menjadi punca utama kepada berlakunya konflik rumah tangga.

Selain itu, hasil analisis juga mendapati penghayatan Islam berperanan secara tidak langsung dalam konflik rumah tangga. Ianya menjadi asas yang dapat memberi ketenangan kepada pengamalnya dalam menghadapi situasi yang tegang. Ketenangan ini diperlukan bagi membendung sesuatu masalah menjadi lebih serius dan rumit. Majoriti responden menyatakan ketenangan yang diperolehi dari solat yang khusyuk, perbanyakkan zikir dan membaca alQuran mampu membimbing suami isteri untuk lebih berfikiran rasional dalam setiap tindakan yang diambil. Ia juga boleh menghalang individu dari bertindak terburu-buru dalam membuat keputusan. Sebagaimana yang dinyatakan oleh responden kesepuluh:

"Sebenarnya benda tu ia lebih kepada kesan rohani daripada kesan fizikal..ok kadang bila kita berzikir, hati you akan lembut.. akan lebih cepat tenang..compare you tidak ada [tidak berzikir], ada panas baran..kadang saya dah overlimit, kadang saya istighfar, zikir untuk redakan, then kita dah rasional balik la.. so sembahyang ini semua boleh membuatkan kita lebih tenang untuk berfikir.."(R:10) 
Penghayatan Islam dan Hubungannya dengan Konflik Rumahtangga: Kajian di Unit Rundingcara, Bahagian Undang-Undang Keluarga, Jabatan Agama Islam Selangor

Pada hakikatnya, seseorang yang ditimpa musibah berada dalam keadaan resah, gelisah, keluh resah dan hati tidak tenteram. Namun penawar untuk menghilangkan segala perasaan ini adalah dengan berzikir kepada Allah SWT. Hati orang yang beriman sentiasa merasai ketenangan dan ketenteraman kerana mereka sentiasa mengingati Allah SWT. Mereka juga merasakan Allah SWT dekat dengan mereka walaupun dalam keadaan diri ditimpa musibah. Ia secara tidak langsung mendidik hati supaya redha dan sabar menempuhi segala dugaan. Ini bertepatan dengan firman Allah SWT:

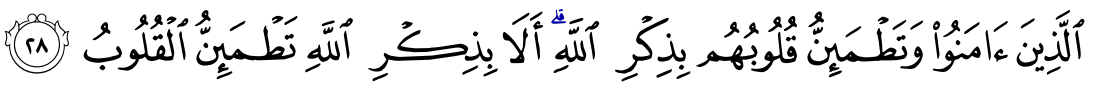

"(Iaitu) orang-orang yang beriman dan tenang tenteram hati mereka dengan zikrullah". Ketahuilah dengan "zikrullah" itu, tenang tenteramlah hati manusia.'

(Surah al-Ra'd, 13: 28)

Malah dapatan kajian juga mendapati, selain ketenangan, penghayatan Islam juga berperanan sebagai salah satu cara yang dapat mendekatkan hamba dengan Penciptanya. Dalam hal ini, individu akan meletakkan pengharapan kepada Allah SWT dalam menyelesaikan sesuatu masalah yang dihadapi Mereka percaya bahawa Allah SWT akan memberi penyelesaian kepada masalah yang dihadapi dan sekali gus mampu menghadapinya dengan tenang. Ianya sebagaimana yang dijelaskan oleh responden ketiga dan kelapan:

“.....dengan solat tu kita memohon kepada Allah kan, dari situlah kalau kita ada masalah, kita merujuk kepada Allah..kalau kita tak merujuk kepada Allah, siapa lagi nak bantu..kawan boleh bantu?(R:3)

"Allah akan bantu..bila dia solat, kita solat, kita cerita kat Allah kan..ya Allah saya ni sakit hati dengan suami saya ni, tapi saya tak nak singgung perasaan dia ni..suami pun cakap ya Allah saya sakit hati dengan isteri saya, tapi saya tak nak singgung perasaan dia, mungkin Allah akan temukan satu titik penyelesaian yang kita dapat selesaikan masalah tu..in shaa Allah.."(R:8)

\section{KESIMPULAN}

Kajian mendapati, penghayatan Islam dari aspek akidah dan ibadah tidak memberi impak yang besar kepada berlakunya konflik dalam rumah tangga. Namun sikap pasangan yang negatif seperti panas baran, keras kepala dan sukar dibawa berbincang adalah antara sikap yang dikesan boleh mendatangkan 
masalah dalam hubungan suami isteri. Sikap negatif ini membawa kepada kesukaran untuk mengadakan perbincangan antara suami isteri bagi menyelesaikan sesuatu masalah berbangkit. Kajian juga mendapati pasangan yang berkonflik berhadapan dengan masalah pengabaian tanggungjawab sebagai suami dan isteri. Ini menunjukkan kurangnya kefahaman mereka tentang ilmu kekeluargaan.

Walau bagaimanapun, kajian mendapati penghayatan Islam berperanan secara tidak langsung sebagai asas yang dapat memberi ketenangan kepada pengamalnya dalam menghadapi situasi yang tegang. Hasil analisis mendapati ketenangan yang diperolehi dari solat yang khusyuk, zikir dan membaca al-Quran mampu membimbing suami isteri untuk lebih berfikiran rasional dalam setiap tindakan yang bakal diambil. Juga boleh menghalang mereka dari bertindak terburu-buru dalam membuat keputusan dan menjadi salah satu wasilah yang menghubungkan hamba dengan Penciptanya untuk memohon jalan penyelesaian kepada masalah yang dihadapi.

\section{RUJUKAN}

Abd Rahim Abd. Rashid, 'Asas Perkahwinan Bahagia dan Punca Kegagalan Perkahwinan,' (Makalah, Seminar Falsafah Perkahwinan, Fakulti Pendidikan, Universiti Malaya, 29-30 Mac 2006).

Abu Hassan Din, Krisis Rumahtangga \& Cara Mengatasinya (Kuala Lumpur: Darul Nu'man, 1996).

Ahmad Sabri Osman, 'Sistem Pendidikan Islam: Suatu Tentang Keberkesanan Penghayatannya di Kalangan Mahasiswa Universiti Teknologi Mara (UiTM) Kampus Arau, Perlis,' (Disertasi Sarjana, Jabatan Sejarah dan Tamadun Islam, Bahagian Pengajian Usuluddin, Akademi Pengajian Islam, 2002).

AlMarri, Tayyiba S.K. et al., 'The Development of the Short Muslim Practice and Belief Scale,' Mental Health, Religion \& Culture, 12/5 (Julai 2009): 415-426.

Azma Mahmood, 'Pengukuran Tahap Penghayatan Pendidikan Islam PelajarPelajar Sekolah Menengah di Malaysia,' (Tesis Kedoktoran, Fakulti Pendidikan, Universiti Kebangsaan Malaysia, 2006).

Berita Harian, 'Satu Perceraian Setiap 15 Minit,' laman sesawang BH Online, http://www.bharian.com.my/bharian/articles/1perceraiansetiap15minit Mashitah/Article/index_html, dicapai 28 Disember 2013. 
Penghayatan Islam dan Hubungannya dengan Konflik Rumahtangga: Kajian di Unit Rundingcara, Bahagian Undang-Undang Keluarga, Jabatan Agama Islam Selangor

Berita Harian, 'Tiga Kes Cerai dalam Satu Jam,' laman sesawang BH Online, http://www.bharian.com.my/bharian/articles/Tigakesceraidalam1jam/ Article, dicapai 28 Disember 2013.

Brandt, Sarah, 'Religious Homogamy and Marital Satisfaction: Couples that Pray Together, Stay Together,' (Student Paper, PSS Annual Meeting, October 2003), 11-20.

Butler, Mark H. et al., 'Prayer As A Conflict Resolution Ritual: Clinical Implications of Religious Couples,' The American Journal of Family Therapy, 30 (2002): 19-37.

Dollahite, David C. \& Lambert, Nathaniel M., 'Forsaking All Others: How Religious Involvement Promotes Marital Fidelity in Christian, Jewish, and Muslim Couples,' Review of Religious Research, 48/3 (2007): 290307.

al-Fayrūzābādī, Muḥammad Ibn Ya'qūb, al-Qāmūs al-Muḥịt, vol. 2 (alQāhirah: Maktabah Dār al-Ma'mūn, 1938).

Goodman, Michael A. \& Dollahite, David C., 'How Religious Couples Perceive the Influence of God in Their Marriage,' Review of Religious Research, 48/2 (2006): 141-155.

Hunler, Olga S. \& Gencoz, Tulin, 'The Effect Of Religiousness On Marital Satisfaction: Testing Themediator Role of Marital Problem Solving Between Religiousness and Marital Satisfaction Relationship,' Contemporary Family Therapy, 27/1 (2005): 123-137.

Ibn Manẓūr, Muhammad Ibn Mukarram, Lisān al-'Arab, vol. 3 (Beirūt: Dār al-Ṣādir, 1994).

Ibn Miskawayh, Aḥmad Ibn Muḥammad, Tahdhīb al-Akhlāq (Beirūt: Manshūrāt Dār Maktabat al-Hayāt, 1961).

Jamiah Manap et al., 'Prinsip Pengukuran Religiositi dan Personaliti Muslim,' Journal of Psychology \& Human Development, 36/1 (2013): 36-43.

Jawiyah Dakir, 'Asas Pembentukan Keluarga Menurut Perspektif al-Qur'an dan al-Sunnah,' Islamiyyat, 17 (1996): 3-18.

Madkūr, Muhammad Sallām, al-Madkhal ila al-Fiqh al-Islāmī, vol. 1 (alQāhirah: al-Dār al-Qawmiyyah, 1955).

Mahoney, Annette, 'Religion and Conflict in Marital and Parent-Child Relationships,' Journal of Social Issues, 61/4 (2005): 689-706.

Mubārak, Zākī, Akhlāq 'inda al-Ghazālī (al-Qāhirah: al-Sha'ab, 1971).

Mușțafā, Ibrāhīm et al., al-Mu 'jam al-Wasịṭ, vol. 1 (Istanbul: Maktabah alIslāmiyyah, 1972). 
Nor Dalilah Zakaria, 'Perlaksanaan Ibadat Solat Hubungannya dengan Konflik Rumah Tangga: Kajian di Unit Rundingcara Keluarga, Bahagian Perkahwinan dan Pembangunan Keluarga, Jabatan Agama Islam Wilayah Persekutuan,' (Disertasi Sarjana, Jabatan Fiqh dan Usul, Akademik Pengajian Islam, Universiti Malaya, 2012).

Nor Dalilah Zakaria \& Raihanah Azahari, 'Hubungan Antara Tahap Pelaksanaan Solat Fardu dengan Konflik Rumah Tangga: Kajian di Unit Rundingcara Keluarga (URK) Bahagian Perkahwinan,' Jurnal Syariah, 21/2 (2013): 145-164.

Nor Salimah Abu Mansor, 'Penghayatan Agama Sebagai Wahana Memperkasa Nilai Insan: Kajian Konsep Berdasarkan Pandangan Sarjana Islam,' (Makalah, Seminar Kebangsaan Pengajian Umum, Jabatan Pembangunan Sumber Manusia, Fakulti Pengurusan dan Pembangunan Sumber Manusia, Universiti Teknologi Malaysia, 13-14 Jun 2006).

Norhayati Hamzah, 'Menangani Konflik Institusi Perkahwinan: Analisisi dan Pandangan Al-Qur'an,' (Makalah, Seminar Falsafah Perkahwinan, Pusat Pembangunan Keluarga, Universiti Malaya, 29-30 Mac 2006).

Norliza Ghazali, 'Objektif Perkahwinan: Satu Kajian Khusus Terhadap Kefahaman dan Penghayatan Masyarakat Islam di Kuala Lumpur,' (Disertasi Sarjana, Bahagian Pengajian Syariah, Akademi Pengajian Islam, Universiti Malaya, 1998).

Norsaleha Mohd. Salleh et al., 'Kesahan dan Kebolehpercayaan Instrumen Penghayatan Akidah,' International Journal of Islamic Thought, 3 (Jun 2013): 71-80.

Nur Zahidah Jaapar \& Raihanah Azahari, 'Model Keluarga Bahagia Menurut Islam,’ Jurnal Fiqh, 8 (2011): 25-44.

Petts, Richard J. \& Knoester, Chris, 'Parents' Religious Heterogamy and Children's Well-Being,' Journal for the Scientific Study of Religion, 46/3 (2007): 373-389.

Raihanah Abdullah, 'Alasan Membubarkan Perkahwinan Melalui Fasakh,' Jurnal Syariah, 5/1 (1997): 51-62.

Raihanah Azahari, 'Permasalahan Rumah tangga: Kajian di Unit UndangUndang Keluarga Jabatan Agama Islam Daerah Petaling, Selangor,' Jurnal Syariah, 15/1 (2007): 115-128.

al-Rāzī, Fakhr al-Dīn Muhammad Ibn 'Umar, al-Tafsīr al-Kabīr, vol. 10 (alQāhirah: Mu’assasat al-Mațba'ah al-Islāmiyyah, 1938).

Robison, Linda C., 'Religious Orientation in Enduring Marriage: An Exploratory Study,' Review of Religious Research, 32/3 (1994): 207217. 
Penghayatan Islam dan Hubungannya dengan Konflik Rumahtangga: Kajian di Unit Rundingcara, Bahagian Undang-Undang Keluarga, Jabatan Agama Islam Selangor

Sapinah Mat Salleh, 'Institusi Kekeluargaan Islam: Pemahaman dan Pengamalan dalam Konteks Kekeluargaan Masa Kini dan Peranannya ke Arah Pembentukan Keluarga Bahagia: Tinjauan Khusus di Wilayah Persekutuan Kuala Lumpur,' (Latihan Ilmiah, Jabatan Pengajian Islam, Fakulti Sastera dan Sains Sosial, Universiti Malaya, 1995/1996).

Siti Fatimah Abdul Ghani \& Haslee Sharil Lim Abdullah, 'Perkhidmatan Kaunseling Keluarga: Satu Alternatif dalam Pengurusan Konflik Rumahtangga,' Masalah Pendidikan (2006): 67-79.

Solahuddin Abdul Hamid, 'Penghayatan Agama sebagai Motivasi Keinginan Pencapaian: Kajian Usahawan Melayu Mara Kedah,' (Tesis Kedoktoran, Akademi Pengajian Islam, Universiti Malaya, 2012).

Walijah Ahmad Jamburi, 'Penghayatan Ibadah dalam Kalangan Pelajar Islam: Kajian di Beberapa Buah Sekolah Menengah Kebangsaan di Petaling Jaya, Selangor,' (Disertasi Sarjana, Jabatan Fiqh dan Usul, Akademi Pengajian Islam, Universiti Malaya, 2010).

Wolfinger, Nicholas H. \& Wilcox, W. Bradford, 'Happily Ever After? Religion, Marital Status, Gender and Relationship Quality in Urban Families,' Social Forces, 86/3 (March 2008): 1311-1337.

Zakaria Stapa, Akidah dan Akhlak dalam Kehidupan Muslim (Kuala Lumpur: Utusan Pulications \& Distributors, 1999). 
Jurnal Syariah, Jil. 24, Bil. 3 (2016) 393-422 